\title{
Developing the Assessment and Indicators for Local Institutions in Dealing with Forest Fire Dilemmas
}

\author{
Eko Priyo Purnomo ${ }^{1, * \mathbb{D}}$, Agustiyara Agustiyara ${ }^{1}$, Rijal Ramdani ${ }^{1}$, Dina Wahyu Trisnawati ${ }^{2}$, P.B. Anand ${ }^{3} \mathbb{D}$ \\ and Aqil Teguh Fathani ${ }^{1}$ (D) \\ 1 Department of Government Affairs and Administration, Jusuf Kalla School of Government, University \\ Muhammadiyah Yogyakarta (UMY), Yogyakarta 55183, Indonesia; agustiyara@umy.ac.id (A.A.); \\ rijalramdani@umy.ac.id (R.R.); aqil.teguh.psc19@mail.umy.ac.id (A.T.F.) \\ 2 Department of Agrotechnology, Faculty of Agriculture, Universitas Muhammadiyah Yogyakarta (UMY), \\ Yogyakarta 55183, Indonesia; dina.trisnawati@fp.umy.ac.id \\ 3 Environmental Economics and Public Policy, Bradford Centre for International Development, \\ University of Bradford, Bradford BD7 1AZ, UK; p.b.anand@bradford.ac.uk \\ * Correspondence: eko@umy.ac.id
}

Citation: Purnomo, E.P.; Agustiyara, A.; Ramdani, R.; Trisnawati, D.W.; Anand, P.B.; Fathani, A.T. Developing the Assessment and Indicators for Local Institutions in Dealing with Forest Fire Dilemmas. Forests 2021, 12, 704. https://doi.org/10.3390/ f12060704

Academic Editors:

Rosa Gallardo-Cobos,

Pedro Sánchez-Zamora and Pilar Fernandez-Rebollo

Received: 11 April 2021

Accepted: 26 May 2021

Published: 29 May 2021

Publisher's Note: MDPI stays neutral with regard to jurisdictional claims in published maps and institutional affiliations.

Copyright: (c) 2021 by the authors. Licensee MDPI, Basel, Switzerland. This article is an open access article distributed under the terms and conditions of the Creative Commons Attribution (CC BY) license (https:// creativecommons.org/licenses/by/ $4.0 /)$.

\begin{abstract}
This study is an analysis of the main criteria and indicators utilised in strengthening local institutions in charge of forest management towards dealing with forest fire incidents in Riau Province, Indonesia. Data were collected using in-depth interviews and observation. Out of the 120 questionnaires distributed to stakeholders, 81 responses were received and analysed using Microsoft Excel and with structural equation modelling (SEM) techniques using SPSS and SmartPLS. Four dimensions, including organization, capacity, authority, and governance, were respectively measured using ten indicators. The results showed a significant correlation between local institutions and these dimension variables in highlighting forest management issues. The results suggest a need to strengthen local institutions' institutional arrangements and their capacities in order to ensure the effective management of natural resources, which may be achievable through the support and co-operation of government institutions and communities.
\end{abstract}

Keywords: forest fire; local institutions; forest management

\section{Introduction}

A forest fire can be caused either naturally or by human action. Only $20 \%$ of recorded forest fires were naturally caused, whilst the remaining majority of the incidents were due to human actions [1]. These actions include land use conversion, clearance, mismanagement, and exploitation. Many of these actions have been linked to globalised and extractive activities, such as beef cattle production in Brazil, cocoa production in West Africa, and the palm oil industry in Southeast Asia [2]. In Indonesia, the leading causes of forest fires are land-clearing practices by small-holder farmers for palm oil plantations and the interplay of elite interests [3]. Forest fires in the country have global significance because they cause haze and smog that can potentially affect the entire Southeast Asian region and also increase global $\mathrm{CO}_{2}$ emissions with climate change effects [4]. Therefore, there is a need for an in-depth understanding of the causes and consequences of forest fires [5].

Many studies have examined the critical role of local institutions in dealing with overexploitation of natural resources [6,7]. For example, local institutions have the ability to mitigate disasters by using modern systems combined with the familiarity of the locals to determine the flow of resources, knowledge, and information to different geographical units and social groups [7]. Population growth and development of local roads are causing deforestation, which could be addressed by relevant governmental institutions [8].

Open dialogue can be a tool to build local institutions to ensure forest sustainability. However, this requires capacity, time, institutional space for dialogue among actors, and 
trust building and there are numerous constraints, including unclear responsibilities and organizational inertia [9]. Therefore, there is a need for collaboration at all levels to establish the mechanisms required to achieve sustainable agreements and protect the long-term benefits of forests. The lack of adequate resources, such as finance, knowledge, training, and technology, limits the ability of local units to mitigate forest fires [10]. Several types of research on the annual Indonesian haze have been conducted [11]. However, studies on the capacity of local central institutions to tackle forest fire issues remain scarce.

The aim of this research was to examine the above-mentioned issues and develop the criteria and indicators (CIs) required to strengthen the capacities of local institutions in Indonesia to mitigate forest fires. It is important to evaluate government efforts in strengthening local institutions that tackle forest fire incidents. The dependence of these areas on natural resources should be considered when designing a sustainable forest management framework. Accordingly, this study was conducted in an area with the most intense forest land-use activities in Indonesia and where the worst forest fire incidents have been recorded: the Bengkalis regency of Riau Province [12]. Primary data were collected and then analysed using Microsoft Excel and with structural equation modelling (SEM) techniques using SPSS and SmartPLS. We identified four dimensions, namely organization, capacity, authority, and governance, which were respectively measured using ten indicators.

\section{Literature Review}

\subsection{Institutional Approaches to Resources Management}

Institutions include formal and informal institutions, norms of behaviour, and communitybased arrangements [13,14]. Formal institutions include laws, rules, and regulations while informal institutions include codes of conduct, habits, and customs, and collectively these determine how people shape and organize all forms of repeated and structured interactions, including in families, neighbourhoods, markets, businesses, sporting associations, and places of worship [13-15]. The institutional approach, conceptually, argues that there is a difference between the rules and the players [13].

An organisation is a formal or informal entity defined by common economic purposes and objectives. Meanwhile, "institutions mainly define social practices and interactions between the stakeholders in a game or a code of ethics" [14]. On the contrary, some problems can be observed with this exposition by North. It does not provide sufficient clarity concerning the differences between institutions and organisations [16]. The approach developed by North and Ostrom can help us understand how decision making takes place in a context of interdependence, how rules can construct behaviours, and when such rules may be modified [16]. Such rules may take into account who should be included, who should have voting rights on important decisions, how these decisions are monitored, how violators are punished, and so on. At the outset, the distinction between institution and organisation may not be readily apparent and this can cause some ambiguity and misinterpretation $[17,18]$.

The second ambiguity is the difference between formal and informal restrictions [16]. Certain individuals identify "formal" rules as being legal, while "informal" rules are classified as non-legal, but this might not present a problem. While formal institutions can be considered as having been designed, informal ones can include spontaneous institutions, and there is a distinction between pragmatic and organic organisations [16]. Accordingly, procedures used to represent institutions and rules must be put into practice with great caution. In addition, an institution can also be defined as a body of norms, rules, and practices used in forming stakeholders' behaviour and expectations [19]. Operational rules guide decision makers in permitting and restricting actions, in accumulating regulations to be enforced and procedures to be obeyed, in sharing or omitting information, and in rewarding or punishing actions or the lack of them [14]. Norms have further been explained to be all the settings applied to define appropriate behaviours, create reasonable living without being excessive [14], and facilitate building reputations. 
However, the law is formulated by the government and is applied to society, and it is compulsory because a citizen is not allowed to choose the laws to follow or ignore [20]. The law is also binding on those it affects and has a civic quality consisting of codification, publicity, and enforcement [20]. The law provides the people with rights and promises equal treatment for all [21].

\subsection{Institutions and Agency of Resources Management}

Local government and local authorities can play an important role in identifying, delineating, and controlling natural resources $[20,22,23]$. The institutional method facilitates responding to common tragedies by providing the opportunity to create rules for quantity, method, and time in sustainably producing and utilising resources [14]. However, culture, traditions, and other social structures may result in the emergence of a variety of institutions [24]. To some extent, the exploration and empirical evaluation of socioeconomic or biophysical factors are distinct from institutional influence [14].

Institutions need to be constructed and adjusted by considering the observed multiscale diversity of regulations for social behaviour. The principles of institutional analysis have been modified by Ostrom to develop an institutional analysis and development (IAD) framework, shown in Figure 1, in order to address a range of common pool resources and to "... systematise diagnostic, analytical, and prescriptive capabilities" [14]. Such a framework also supports the accumulation of knowledge from empirical studies and the assessment of previous reforms [20].

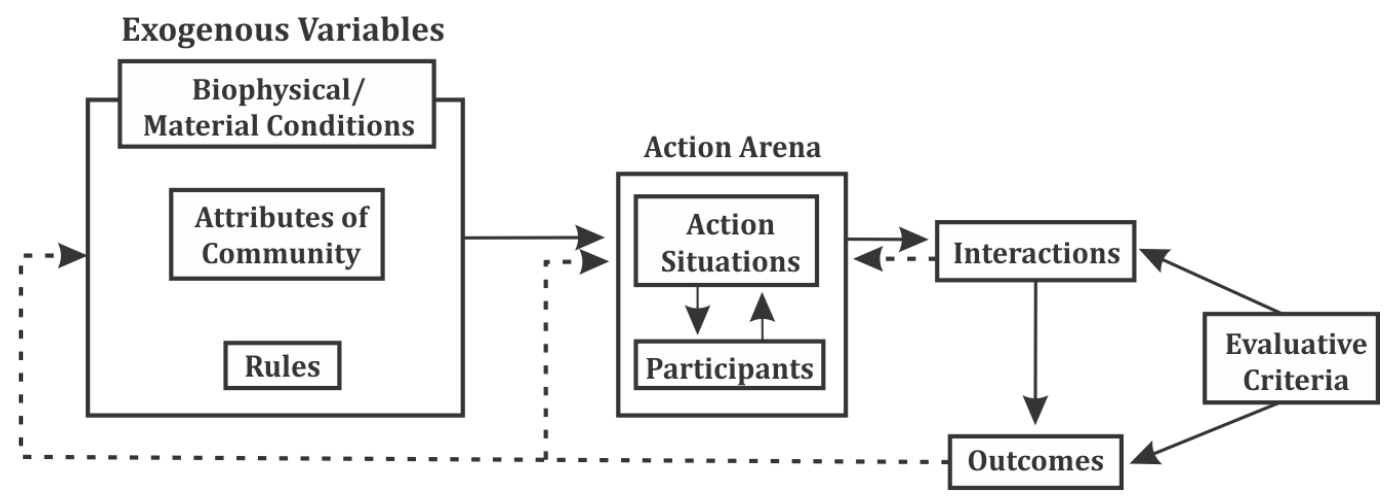

Figure 1. A framework for institutional analysis (source: [14]).

Exogenous variables are outside the model and are thus beyond the decisions and actions of the individuals and institutions we are studying. Hence, this framework is mostly used to set arbitrary external conditions rather than to achieve more realistic behaviour in a model [25]. After understanding the initial structure of an action arena, the institutional analyst can execute two more steps. In the first step, the structure factors are fully explored and evaluated [14] and, from this point of view, the arena functions as a set of variables dependant on other factors [26]. The second step explicitly examines how the common understanding of rules, real world conditions, and the nature of the community affects the values of variables that characterize the field of action [27]. In this case, the formulated policies affect operational decisions made by individuals with a direct impact on the physical world [19].

Previous studies have examined institutions relating to decentralized forest management in Riau province and observed the absence of institutionalism in forest governance [28]. Such institutional deficiency can be traced back to the futile expectations of organizations in natural resources management $[29,30]$. As already mentioned, there are many reasons why local institutions are required to manage resources sustainably [31]. First, government policies have failed due to the scarcity of the resources, such as funding and human resources, needed to support the intended targets [26]. Second, local selforganization is capable of adapting to the common resources dilemma and promoting 
sustainable utilization $[14,24,32]$. Third, most policies rely on textbooks and are often indifferent to what is happening on the ground, making local contexts the best area for strategy to be employed [33]. Additionally, participation is considered a key method for redistributing and reassigning resources $[34,35]$.

There are several other strategies that must also be considered in developing community performance [35]. Improving the promotion of the decentralization and participation of local institutions in managing and reallocating natural resources is an appropriate measure [36]. A further measure is the creation of a legal framework to establish rules and enforce laws. Furthermore, equal relationships should be maintained with other stakeholders, like local authorities and investors [37]. Institutional transparency is also needed to support the information-equality system among stakeholders and, finally, the flexibility and adaptation of cooperative partnerships are of no less importance. Natural resource management should be built with an effective, equitable, and efficient system [38]. In this case, effectiveness is expected to deal with the public's short-term interest, while the long-term objectives must ensure sustainability. Moreover, equitability should address the diversity of stakeholders, while efficiency must ensure reasonable costs for gathering information and implementing, monitoring, and enforcing the policy [39]. This therefore shows that good natural resource management is a combination of several indicators and requirements linking and complementing each other. For this research, the analysis of selected local institutions in managing natural resources has several criteria and ten indicators, as shown in Figure 1, with those in bold characters being the main focus.

\section{Materials and Methods}

Fieldwork was conducted in Riau Province, mainly in Bengkalis regency, because of the high rate of forest fires and deforestation in the area; furthermore, more than half of the forest fires occurred in the peatland areas. In this province, the tropical lowland rainforests have degraded not only due to the forest fires but also due to the conversion of forests into areas for monoculture cash crops, such as oil palm and pulpwood plantations [40]. Deforestation has become a significant danger not only to Indonesia but also to the global environment [41]. Moreover, the Bengkalis regency has experienced the highest number of forest fires, with seven sub-districts recorded to be significantly vulnerable [41].

The annual haze was observed from 2004 to 2016, which later led the provincial and regional governments to implement more than 15 regulations. Furthermore, there were over 98 government agencies tasked to manage the issue. However, there has been limited involvement from the local community. Data were gathered using questionnaires that were designed to provide demographic information and obtain responses to inquiries concerning variables under a composite and reflective measurement model related to the stakeholders. In this study, by "stakeholders" we mean the public servants in the provincial, regional, sub-district, and village office levels; activists from environmental nongovernmental organizations (ENGOs); small-holder palm oil farmers; fire care community (FCC) members; and villagers living in and around the forest areas (Table 1). Factors affecting local institutions, such as organization, authority, governance, and capacity, as well as the impacts of each of these variables on each other, were included in the analysis. From a total of 112 questionnaires distributed to these stakeholders, 81 were completed (giving a response rate of $72.5 \%$ ) and then analysed. The remaining 31 were dropped due to incomplete and invalid responses. Moreover, maintaining completeness and validity in order to provide a comprehensive picture of all the interested parties and their respective degrees of participation in forest management from 2016 to 2019 was considered crucial. 
Table 1. Figures for the selected stakeholders and respondents.

\begin{tabular}{|c|c|c|c|c|c|c|}
\hline \multicolumn{7}{|c|}{ Count } \\
\hline & & \multicolumn{4}{|c|}{$\mathrm{X} 2$} & \multirow{2}{*}{ Total } \\
\hline & & Chairs of Institutions & Members of Boards & Staff & Society & \\
\hline \multirow{5}{*}{$\mathrm{X} 1$} & Province & 28 & 0 & 0 & 0 & $28(35 \%)$ \\
\hline & Regency & 1 & 18 & 1 & 0 & $20(23.8 \%)$ \\
\hline & Villages & & & & & \\
\hline & $\begin{array}{l}\text { (small-holders, fire } \\
\text { care community } \\
(\text { FCC }))\end{array}$ & 0 & 0 & 20 & 2 & $22(27.5 \%)$ \\
\hline & NGOs & 0 & 0 & 0 & 11 & $11(13.8 \%)$ \\
\hline \multicolumn{2}{|r|}{ Total } & $\begin{array}{c}29 \\
(36.3 \%)\end{array}$ & $\begin{array}{c}18 \\
(21.3 \%)\end{array}$ & $\begin{array}{c}21 \\
(26.3 \%)\end{array}$ & $\begin{array}{c}13 \\
(16.3 \%)\end{array}$ & $\begin{array}{c}81 \\
(100 \%)\end{array}$ \\
\hline
\end{tabular}

Microsoft Excel was used to organize the data. Statistical Packages for Social Sciences (SPSS) and SmartPLS were used to analyse and create a structural equation model, respectively. SEM has been suggested by Hair et al. (2014) for use in exploratory research [42]. In most cases, the equation with the highest number of independent variables is considered to determine the minimum number of observations needed to detect an effect reliably. The equation is formed as follows:

$$
\mathrm{Y}=\alpha+\mathrm{b} 1 \mathrm{X} 1+\mathrm{b} 2 \mathrm{X} 2+\mathrm{b} 3 \mathrm{X} 3+\mathrm{b} 4 \mathrm{X} 4+\mathrm{e}
$$

where $\mathrm{Y}=$ institution, $\mathrm{X} 1$ = organization, $\mathrm{X} 2=$ capacity, $\mathrm{X} 3=$ authority, $\mathrm{X} 4$ = governance, $\mathrm{b} 1, \ldots \mathrm{b} 4=$ coefficients, $\alpha=$ constant, and $\mathrm{e}=$ error.

The model analysed the welding process of the variables and resolved them by assessing the larger values under a regular probabilistic model with different software, such as AMOS, EQS, and Mplus [43]. As indicated earlier in this article, SmartPLS was also deployed for this model by using the partial least squares method to analyse the differential composition of the variables. This method has low requirements and considers the range of measurements, number of samples, irregularities, and residual distributions [44]. This method and software are part of a growing trend in academic research, and they are based on regression. A component-centred approach was utilised to depict the directed dependencies among a series of variables [42]. SmartPLS analysis suggested a minimum sample size of 81 informants, assuming a medium effect size (f2 $=0.150)$, a statistical power of 0.8 , and a significance level of 0.05 [45]. In its current form, PLS-PM is a full-fledged variance-based estimator with the ability to estimate linear, nonlinear, recursive, and nonrecursive structural models. It is capable of dealing with models containing new and latent variables [5].

SmartPLS was used in an iterative method to assess latent variables through two different types of manipulations. First, it aided the computation based on the relationship between observable and latent variables using an outer estimation approach. In this study, institutions were used as the latent variables and assessed using the linear combination of observable factors, such as organization, capacity, and authority. The bootstrapping of SmartPLS was used to conduct a significance test on the indicators in the local institution. Table 2 shows that all the indicators were retained and able to describe the management of natural resources, as presented in Figure 2. The impacts of several factors on local institutions were also observed to be significant in terms of forestry management. Correlation and partial-correlation analyses were conducted to determine the indicators' correlations with the dependent variables. 
Table 2. Correlation results for significant variables (dimensions) related to strengthening local institutions, 2020.

\begin{tabular}{|c|c|c|c|c|c|}
\hline \multicolumn{2}{|c|}{ Organization } & Authority & Capacity & Governance & Institution \\
\hline \multicolumn{2}{|l|}{ Clearness_of_policy } & 0.616 & & & \\
\hline \multicolumn{2}{|l|}{ Community_access } & & 0.676 & & \\
\hline \multicolumn{2}{|c|}{ Community_depending_resources } & & 0.201 & & \\
\hline \multicolumn{2}{|c|}{ Community_engagement } & 0.099 & & & \\
\hline Controlling & 0.566 & & & & \\
\hline Distribution & & & 0.114 & & \\
\hline Economic_activities & & 0.352 & & & \\
\hline Equity & & & & 0.412 & \\
\hline Forest_access & & -0.063 & & & \\
\hline Forest_fires & 0.204 & & & & \\
\hline Forest_income & & 0.530 & & & \\
\hline Forest_management & & & & 0.469 & \\
\hline Forest_production & & -0.226 & & & \\
\hline Forest_administratio & & 0.330 & & & \\
\hline Forest_allocation & & 0.213 & & & \\
\hline Forest_for_benefits & & 0.033 & & & \\
\hline Forest_issues & 0.433 & & & & \\
\hline Forestry & & & & & 1.000 \\
\hline Function & 0.111 & & & & \\
\hline Government_roles & -0.091 & & & & \\
\hline Information_distribu & tion & & 0.402 & & \\
\hline Knowledge_understa & nding & & 0.130 & & \\
\hline Knowledge_land_use & & & 0.139 & & \\
\hline Land_owner_particip & ation & & & 0.257 & \\
\hline Legality & & & & -0.084 & \\
\hline Local_engagement & -0.379 & & & & \\
\hline Market_demands & & 0.240 & & & \\
\hline Multi_stakeholders & & & & 0.176 & \\
\hline Mutual_understandi & & & 0.149 & & \\
\hline Organization_functio & & & & -0.329 & \\
\hline Ownership & & & & -0.429 & \\
\hline Participation & & & 0.480 & & \\
\hline Performance & & & 0.503 & & \\
\hline Personnel & 0.352 & & & & \\
\hline Political_interest & & & & 0.285 & \\
\hline Professionalism & 0.638 & & & & \\
\hline Regulated & & & 0.390 & & \\
\hline Role_changes & 0.005 & & & & \\
\hline Stakeholders_roles & & & & 0.739 & \\
\hline Uncoordinated_regu & ation & & & -0.176 & \\
\hline Operational & 0.495 & & & & \\
\hline
\end{tabular}




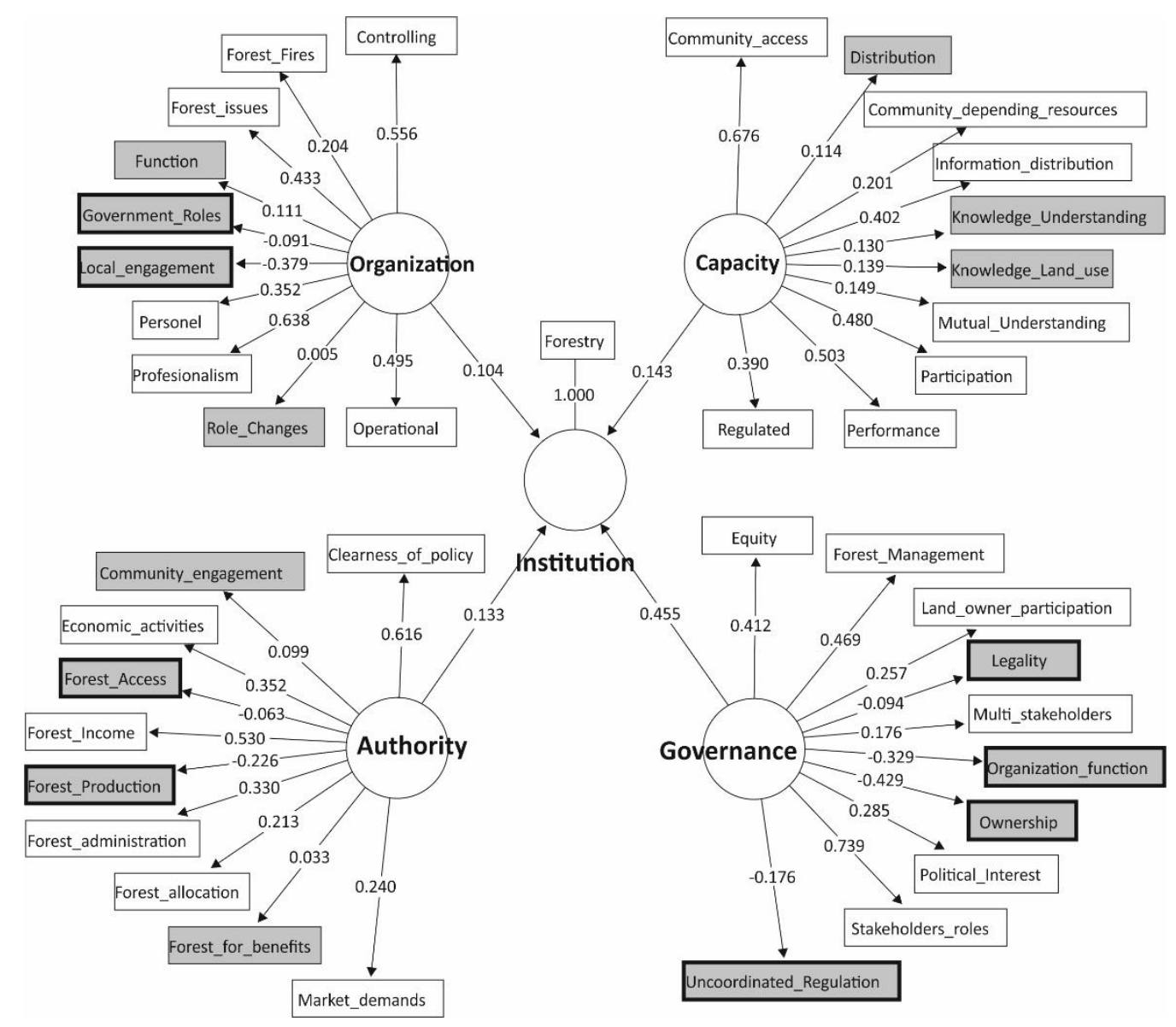

Figure 2. Development and measurement of indicators to strengthen institutions, 2020 (source: analysed and visualised with SmartPLS 2020).

\section{Results}

All criteria and indicators used were adapted from the literature and adjusted to fit the objective and context of this study [14,24,35-48]. Moreover, significant impacts of the four variables and the other ten indicators were observed on the local institutions, and this was true for all the variables that did not attenuate the relevant coefficient. The variations between local institutions and formalization of forest governance through institutionalism were established.

The correlation between governance and local institutions was initially described by determining the significant and insignificant variables [49]. As posited, the relationship between local institutions and the proposed variables was significant. The empirical result was consistent with previous studies, showing that some factors of forest management exhibited significant effects on local institutions. Surprisingly, 4 of the 15 values contributed significantly to the total indicators according to the analysed questionnaire data. The informants indicated how much they agreed with these statements using a five-point Likert scale ranging from "totally disagree" to "totally agree," after which the responses were categorized. The institution with four indicators and an additional sub-variable from the questionnaire was used as the primary variable, as shown in Table 2 . The results showed that the four indicators were part of the most significant issues affecting forest management, as presented in Figure 2, while the other indicators had no significant relationships.

The constructs were applied to measure the institution variables, including organization, capacity, authority, and governance, with the use of PLS software, which is reported to be a full-fledged estimator with the ability to deal with reflective and causal-formative measurement, as well as composite models. In this study, variables and indicators were the first step of regression and were followed by the independent constructs, which were 
assessed simultaneously to ensure that their effects were noticeable in the model. Structural equation modelling includes latent variables, which are drawn as circles. Observed or measured variables are shown as squares. Moreover, the equations of the institution model specify the hypothesized relationships among latent variables. We include one hypothesized structural model in the composite model in Figure 2. In the institution model, we figured out the significant and non-significant correlations between the variables that were presented in the regression results of the local institution models. The preferences and attitudes of actors towards other organizations and their involvement in forest governance were examined and the influence of organizations, authority, capacity, and governance on institutions was also evaluated. The results demonstrated the positive and significant effects that these indicators have on encouraging local institutions in forest management, as shown in Figure 3, with the significant variables marked in grey with bold script and the insignificant ones in white.

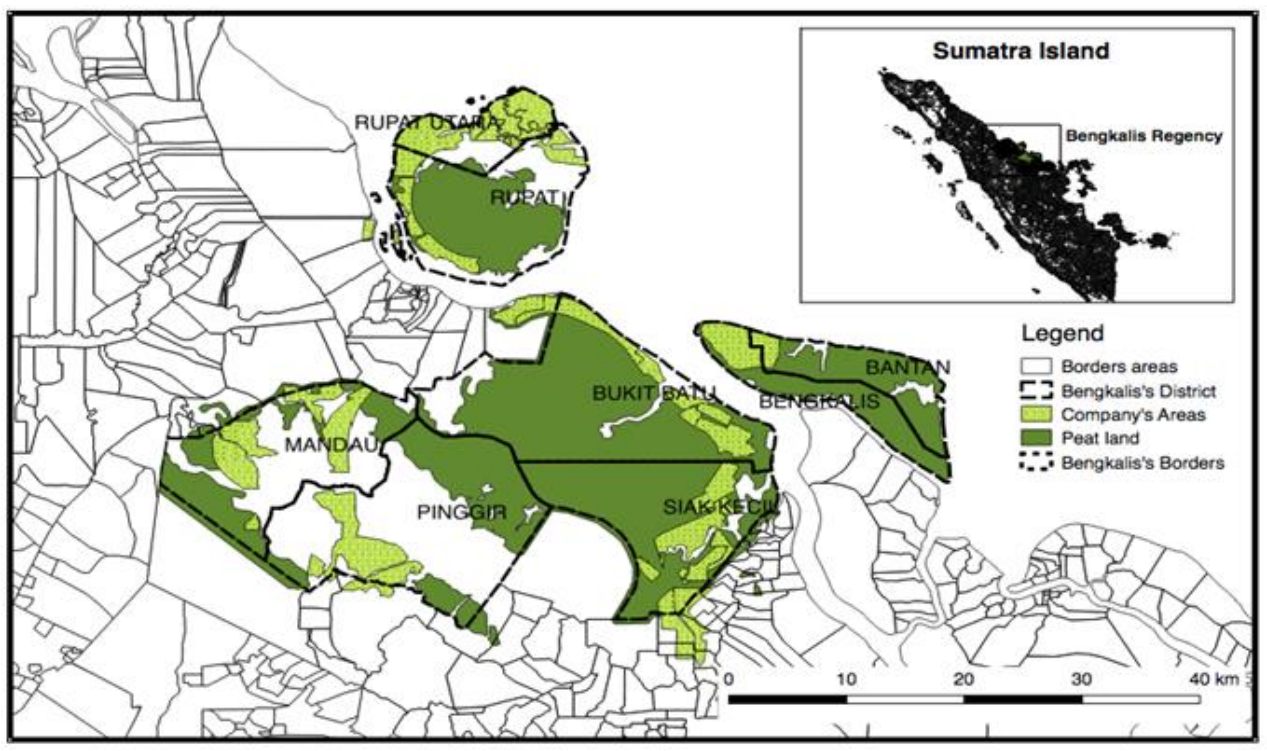

Figure 3. Bengkalis, Riau Province, in Sumatra Island, Indonesia (source: modified with Q-GIS, 2020).

Dimension 1-organization: Based upon the analysis, four indicators had statistical significance in relation to organization, namely government roles, with a $p$-value of -0.091 ; local engagement, with -0.379 ; role changes, with 0.005 ; and function, with 0.111 . The level of confidence used in this research was 95\%; hence, a $p$-value equal to or less than 0.5 was considered acceptable $[50,51]$. The results showed that a conceptual model is very important in explaining the formation of local institutions. The "government roles" variable can provide authority and clarity, promote successful collective action, and reflect the importance of cultural context when designing institutions [20,52]. The potential effect on local engagement and role changes of the related institutions was also analysed, and regulations were found to exist only "on paper", without any form of practical application for local engagement. For example, forest monitoring and evaluation, as an effort to organize and engage the local community, involve patrols that are expected to be regulated by the government to ensure that resources from forest areas are not extracted illegally or legally.

Dimension 2-authority: Based upon the analysis, four indicators were found to be significant in relation to authority: community engagement, with a $p$-value of 0.09 ; forest access, with -0.063 ; forest production, with -0.226 ; and forest for benefits, with 0.033 . Even though these values were considered significant [48], a significance level of less than 0.05 could be considered accepTABLE depending on the measurement used. The institutional structure was suspected to be established based on the authority to falsify community engagement and strengthen value-based forest access in order to increase the 
income and incentives of small-holders involved in forest governance activities. Moreover, government authority was found to be required throughout the supply chain and to ensure traceability throughout the structure. Hence, government authority creates rigidity in resolving forest governance [23].

Similarly, Dimensions 3 and 4, which were capacity and governance, respectively, also had verified relationships with the institution model. The regression coefficients showed that the indicators of capacity were significant, as observed in relation to distribution, which had a $p$-value of 0.114; knowledge understanding, at 0.130; and knowledge on land use, with 0.039 . However, despite their high values, it is possible to consider them as acceptable, depending on the measuring method [52]. The indicators of governance were found to influence local institutions, as indicated by the $p$-values recorded for legality, which was -0.084 ; organization function, at -0.329 ; ownership, at -0.429 ; and uncoordinated regulation, at -0.176 . These factors were judged to be very important in strengthening local institutions. For example, the government needs to provide legal protection for communities in terms of forest land-use access because there may be overlapping land ownership statuses due to uncoordinated regulations. The consistent PLS (PLSc) algorithm was deployed to ensure the consistency of the results with the factors used. The model showed a significant effect of the coefficient on the institutionalism model, as indicated in the overall results presented in Table 2.

Previous studies contend that institutional quality affects institutional performance $[14,48,53,54]$. Institutional structures are also believed to be dependent on variables such as institutional-based organizations, which consist of functions like government roles, integration of natural resources from different sectors, and local government units [55]. Furthermore, local engagement and uncoordinated regulation contain some norms and legal systems at the societal level, ease the risk-taking process, and strengthen institutions. Stable legal, political, and social engagement significantly affects sub-national institutions and meaningful political decentralization [48].

Institution-based authority focuses on how and when government institutions attempt to perform their authority and successfully strengthen institutions for ecological sustainability through local engagement [56]. This is important in situations where significant and insignificant indicators are relatively weak and fragmented. For example, if economic activities are largely unregulated, the efforts of governmental bodies to convey and resolve those problems among distinct groups and stakeholders will not be easy to consider in terms of the results of indicators of forest production and forest benefits in the process of strengthening local institutions.

Concerning institution-based governance and institution-based capacity, the administrative function was found to reflect natural resource governance while forest land use and land-use knowledge were found to control the legality and ownership of the land [6,57]. Moreover, forest governance involves the participation and shared management responsibilities of local institutions through coordinated regulations and functions [58]. However, having a lesser capacity can result in a lack of resources and accountability, while an insufficient transfer of power can affect governance by causing the marginalization of the local community.

Some areas of interest for the development of local institutions include ownership, organizational function, uncoordinated regulation, local participation in forest resource access and allocation, institutional values at differing levels of local government, recognition of the differences among groups with conflicting interests, and ensuring sustainability [59]. It is essential to understand the impact of local institutions and collaborations among actors on forest governance. In order to facilitate effective utilization of natural resources, local communities with strong informal institutions should be encouraged and strengthened. This is necessary because forest governance evolves out of hierarchy or authority based on the influence of several institutions and political movements, and this has resulted in many communities lacking functioning administrative institutions, adequate boundaries, and the organizational capacity to manage access to forest lands [53]. 


\section{Discussion}

Four significant variables, namely ownership, organization function, uncoordinated regulation, and local engagement, were tested and found to affect the process of strengthening local institutions. The results were reasonably consistent with the model since additional variables were discovered to lack significance in relation to the measurement, as shown in Figure 2. The results highlight some factors to focus on, including land ownership, small-holder farmers, local elites, and industrial plantation sectors. In this case, the small-holders in the surrounding forests have been observed to lack coordination in land distribution. Hence, the major weaknesses of local institutions are the lack of flexibility and inertia with regard to innovation, thereby resulting in unequal land distribution and deforestation $[48,60]$. In addition, local engagement should be encouraged to integrate those who own and manage land through participation in forest governance practices, while the government should transparently formulate and enforce adequate regulations through organizational functions with related institutions.

The correlations between these variables and efforts towards strengthening local institutions in forest management were examined through analysis with SmartPLS of forest land-use groups in the Bengkalis regency. The results show that formal institutions alone are less effective in the sustainable management of local resources [61] because they are typically designed for a particular purpose [52]. This is not to say that formal institutions are not at all needed but that, on their own, they are not the solution to the complex problems of forest management. They need to be adaptable and dynamic and the formal institutions need other informal institutions that temper, regulate, oversee, and monitor their behaviour through norms and citizen involvement. For this, civil society institutions and other forms of local deliberative forums are crucial. This argument needs further support through thorough studies [14,24,32]. Local self-organization was also found to be a useful means to solve the common resources issue and enhance natural resources utilization.

Furthermore, it is important to understand the concept of local institutions in terms of disentangling institutional features, such as the lack of government recognition of the twoway relationship between institutions and natural resource management, which is reflected in their weak role in forest management. The importance of appropriate institutions in empowering local communities to reduce threats and improve forest conditions has also been emphasised [62]. However, a standard approach was used to measure local institutions with different variations observed in the results, ranging from variables with significant correlations to those with none, See Figure 4.

The estimated variables and adjusted coefficients show that the significant influences of organization, authority, governance, and capacity on local institutions are likely to be driven by the observed variables. Moreover, Figure 2 shows a substantial relationship between institution and governance in terms of forest management. This means that when there is a lack of forest governance, other variables, such as organization, authority, and capacity, are equally insignificant in promoting sustainable and profitable forest management. There is a need for the local government to continuously engage with stakeholders in the management of forest resources. For instance, the community can be tasked to manage one of the institutions in the long run and to produce the best form of governance; there is thus a need for the provision of significant organization, authority, and capacity. The findings also show that the disintegration of institutional norms indirectly increases illegal logging and degradation and, consequently, reduces the carrying capacity of the forests due to insignificant values of pressures. 


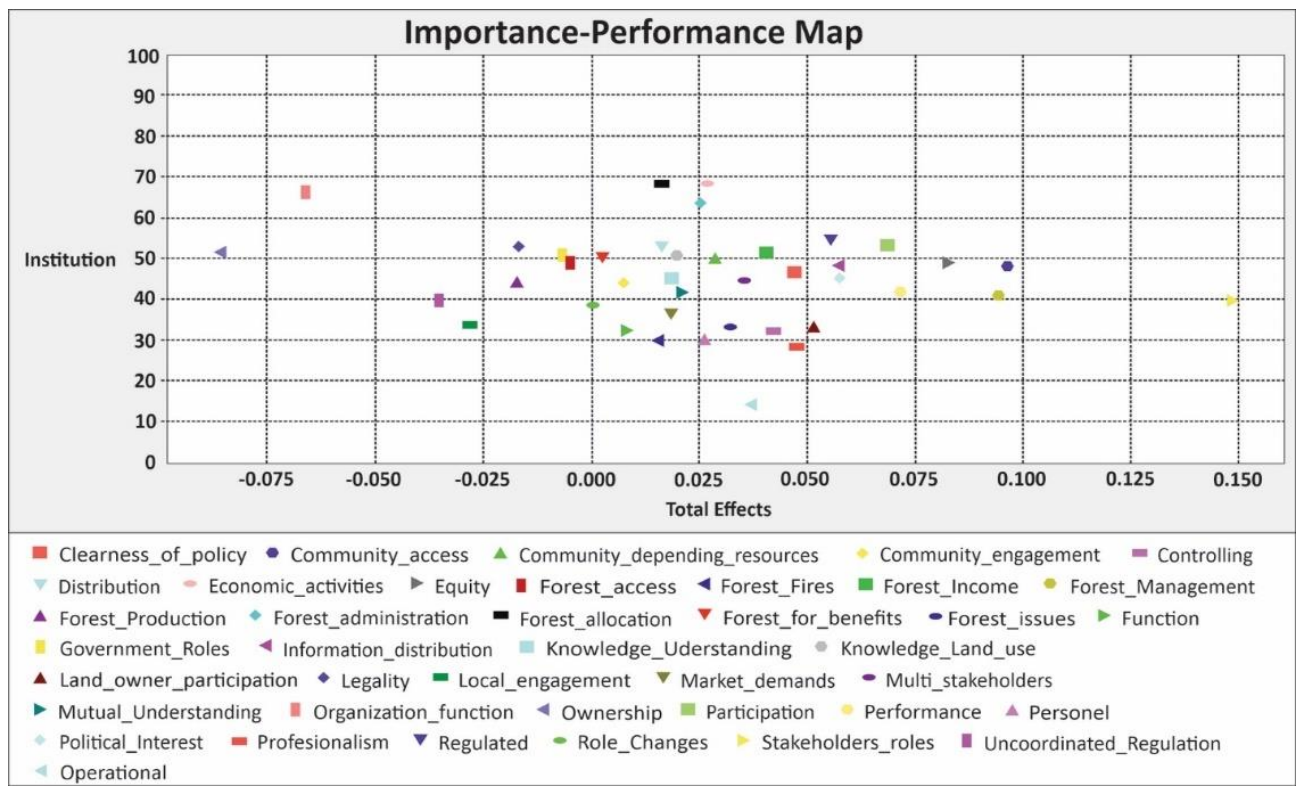

Figure 4. Scatter plot of correlations between local institutions and the indicators' variables in the Bengkalis regency (source: analysed and visualised with SmartPLS 2020).

Moreover, strengthening the functions of local institutions in the management of forest systems is expected to have a tendency to become more challenging in the future due to the absence of multi-stakeholders. This means that the inclusion and involvement of stakeholders are required, as observed in the values obtained for ownership, organization function, uncoordinated regulation, and local engagement indicators. Local communities, when empowered with sufficient information, transparency, and organizational capacity, have the ability to utilize natural resources in such a way as to reduce their reliance on the forest, as observed in the improvements in institutional quality and forest quality recorded with institution-based communities. This also helps to enhance local institutions and produce more benefits from forest resource management by which society can derive more uses from biodiversity.

In terms of ownership, three categories were identified: first, areas where forest utilization rights have not changed, and the trees are still standing; second, forest areas that have been cultivated or have degraded lands, which most areas in Bengkalis are categorized as; and third, overgrown or planted forests with land degraded by agricultural practices. However, changes in land use were reported to have rapidly increased due to several factors, such as high population growth and migration driven by oil palm plantations. Substantial changes in ownership of burned lands were observed in transfers from private ownership to elite businesses or political actors, as well as through self-identified factors motivated by profit-oriented activities [37]. Local communities are the main actors in the decentralized management of natural resources [24]. This is associated with the key role they play in shaping outcomes by being the beneficiaries of positive results and the victims of negative ones.

The ability of the organizational function to strengthen local institutions is based on smaller administrative villages, desa, and this results in an overlap in the rules and functions of forest management, leading to problems among stakeholders at the district, sub-district, and village levels. Theoretically, the relationship between organizational and institutional functions is initially assessed through changes in local institutions. At the same time, decentralization ideally includes the distribution of rights and the authority to manage resources to local communities or local government organizations [35,63,64].

While we have shown that formal institutions alone are not a total solution, strong organizational function and dynamic local institutions are still required for the successful implementation of natural resources management $[14,35]$. Uncoordinated regulation can 
restrict the capacity of these institutions to manage and use resources effectively. Stability requires strong and fixed regulations but this may result in rigidity and subsequently lead to the bypassing of regulations through corrupt practices. The need for stable regulation should be counterbalanced by the flexibility and adaptability of local level institutions. This requires a dynamic set of regulations and the capacity to provide transparent and dynamic negotiation processes or threshold conditions to allow for relaxing the regulations. The government needs to formulate forest-based regulations at the village level and involve multi-stakeholders to ensure efficient enforcement. Furthermore, another key factor is local management, as indicated by the capacity for planning and the lack of knowledge regarding forest land-use management. Therefore, the structure of local institutions needs to be strengthened by integrating local engagements in sustainable management practices to ensure reduced deforestation and forest degradation.

\section{Conclusions}

The current study aimed to make an original contribution with regard to institutional arrangements and dynamics in forest management and governance and how these can help reduce forest fires or improve the regulation of forest use by engaging local stakeholders and empowering such stakeholder communities. We developed and used four criteria and 40 indicators in this study. In the context of the organization, four indicators, namely government roles, local engagement, role changes, and function, were found to be significant; however, only government roles and local engagement had substantial influences on efforts to strengthen local institutions. In terms of authority, four indicators were also observed to have a significant influence-community engagement, forest access, forest production, and forest benefits. However, forest access and forest production should be prioritized due to their high values.

Capacity and governance also confirmed the model's linkages. The regression results indicated that capacity measures such as distribution, knowledge, comprehension, and knowledge of land use were all significant. Additionally, governance factors such as legality, organisational function, ownership, and uncoordinated regulation were determined to be relevant. However, the most important factors influencing local institutions were found to be legitimacy, administrative structure, ownership, and uncoordinated control.

The results exhibit the complexity of local institutions in forestry management in the Bengkalis regency. The pursuit of governance supported by organization, authority, and capacity is required in order to effectively reduce pressure on forest resources, such as measurement based on current issues, as observed with ownership, organization function, uncoordinated regulation, and local engagement. This can help to strengthen local institutions in sustainable forest management. With regard to the policy issue, institutional arrangements with a capacity to ensure effective natural resource management may be achieved with the support and cooperation of government institutions and communities.

Author Contributions: Conceptualization, E.P.P., P.B.A. and A.A.; methodology, A.A.; software, A.A. and A.T.F.; validation, R.R.; formal analysis, E.P.P.; investigation, E.P.P.; resources, E.P.P.; data curation, R.R., D.W.T. and A.T.F.; writing-original draft preparation, E.P.P., A.A., R.R.; writing-review and editing, E.P.P., A.A., R.R., D.W.T., P.B.A., A.T.F.; visualization, A.A.; supervision, P.B.A.; project administration, E.P.P. and R.R.; funding acquisition, E.P.P. All authors have read and agreed to the published version of the manuscript.

Funding: This research received no external funding.

Informed Consent Statement: Not applicable.

Data Availability Statement: The data presented in this study are available on request from the corresponding author. The data are not publicly available due to some are include informants' names and identity. 
Acknowledgments: We would also like to show our gratitude to the blind reviewers and the editor for giving us very constructive comments and suggestions. We would also thank to Klaus Hubacek from the University of Groningen, the Netherlands, Sataporn Roengtam from Khon Kaen University, Thailand and Achmad Nurmandi from Universitas Muhammadiyah Yogyakarta, Indonesia who provided insight and expertise that greatly assisted the research. We would like to thank to our proof-reader, Asmanta P Susatya. In addition, the authors are thankful to the interviewees of the study area for providing valuable information and some institutions such as the Ministry of Research, Technology and Higher Education of the Republic of Indonesia, and Jusuf Kalla School of Government team, Universitas Muhammadiyah Yogyakarta, and AIFIS/Henry Luce Foundation.

Conflicts of Interest: No Potential conflict of interest was reported by the authors.

\section{References}

1. Vasudeva, S.P. Disastrous Forest Fires: Management and Control. Indian J. Public Adm. 2018, 64, 237-253. [CrossRef]

2. Miettinen, J.; Shi, C.; Liew, S.C. Two decades of destruction in Southeast Asia's peat swamp forests. Front. Ecol. Environ. 2012, 10, 124-128. [CrossRef]

3. Purnomo, E.P.; Anand, P.B.; Choi, J.-W. The complexity and consequences of the policy implementation dealing with sustainable ideas. J. Sustain. For. 2018, 37, 270-285. [CrossRef]

4. Wolff, N.H.; Masuda, Y.J.; Meijaard, E.; Wells, J.A.; Game, E.T. Impacts of tropical deforestation on local temperature and human well-being perceptions. Glob. Environ. Chang. 2018, 52, 181-189. [CrossRef]

5. Ramdani, R.; Lounela, A.K. Palm oil expansion in tropical peatland: Distrust between advocacy and service environmental NGOs. For. Policy Econ. 2020, 118, 102242. [CrossRef]

6. Andersson, F.; Mårell, A.; Andersson, F.; Mårell, A. A European Network in Support of Sustainable Forest Management A European Network in Support of Sustainable Forest Management. J. Sustain. For. 2017, 24, 279-293. [CrossRef]

7. Tiwari, P.C.; Joshi, B. Local and regional institutions and environmental governance in Hindu Kush Himalaya. Environ. Sci. 2015, 49, 66-74. [CrossRef]

8. Andersson, K. Understanding decentralized forest governance: An application of the institutional analysis and development framework. Sustain. Sci. Pract. Policy 2017, 2, 25-35. [CrossRef]

9. Moeliono, M.; Santoso, L.; Gallemore, C. REDD+ Policy Networks in Indonesia; Center for International Forestry Research (CIFOR): Borgor, Indonesia, 2013.

10. Herawati, H.; Santoso, H. Tropical forest susceptibility to and risk of fire under changing climate: A review of fire nature, policy and institutions in Indonesia. For. Policy Econ. 2011, 13, 227-233. [CrossRef]

11. Sahide, M.A.K.; Nurrochmat, D.R.; Giessen, L. The regime complex for tropical rainforest transformation: Analysing the relevance of multiple global and regional land use regimes in Indonesia. Land Use Policy 2015, 47, 408-425. [CrossRef]

12. CNN Indonesia. BMKG Sebut Kebakaran Hutan Landa 11 Kabupaten di Riau; CNN Indonesia: Jakarta, Indonesia, 2019.

13. North, D. Institutions, Institutional Change and Economic Performance (Political Economy of Institutions and Decisions); Cambridge University Press: New York, NY, USA, 1991.

14. Ostrom, E. Governing the Commons: The Evolution of Institutions for Collective Action; Cambridge University Press: New York, NY, USA, 2015; ISBN 9781316423936.

15. Hasan, M.A.; Nahiduzzaman, K.M.; Aldosary, A.S. Public participation in EIA: A comparative study of the projects run by government and non-governmental organizations. Environ. Impact Assess. Rev. 2018, 72, 12-24. [CrossRef]

16. Hodgson, D. Conceptualising the compulsory education policy apparatus: Producing and reproducing risky subjectivities. J. Educ. Policy 2017, 0939, 1-16. [CrossRef]

17. Charron, N.; Lapuente, V.; Annoni, P. Measuring quality of government in EU regions across space and time. Pap. Reg. Sci. 2019, 98, 1925-1953. [CrossRef]

18. Alons, G. Environmental policy integration in the EU's common agricultural policy: Greening or greenwashing? J. Eur. Public Policy 2017, 24, 1604-1622. [CrossRef]

19. Agrawal, A.; Ostrom, E. Collective action, property rights, and decentralization in resource use in India and Nepal. Politics Soc. 2001, 29, 4. [CrossRef]

20. Gibson, C.C.; Williams, J.T.; Ostrom, E. Local enforcement and better forests. World Dev. 2005, 33, 273-284. [CrossRef]

21. Smith, J.; Obidzinski, K.; Subarudi, S.; Suramenggala, I. Illegal logging, collusive corruption and fragmented governments in Kalimantan, Indonesia. Int. For. Rev. 2003, 5, 293-302. [CrossRef]

22. Cahill, C.; Sultana, F.; Pain, R. Participatory ethics: Politics, practices, institutions. ACME 2007, 6, 304-318.

23. Li, Q.; Guan, X.; Wu, P.; Wang, X.; Zhou, L.; Tong, Y.; Ren, R.; Leung, K.S.M.; Lau, E.H.Y.; Wong, J.Y.; et al. Early Transmission Dynamics in Wuhan, China, of Novel Coronavirus-Infected Pneumonia. N. Engl. J. Med. 2020, 382, 1199-1207. [CrossRef]

24. Agrawal, A. Common Property Institutions and Sustainable Governance of Resources. World Dev. 2001, 29, 1649-1672. [CrossRef]

25. Purnomo, E.P.; Loilatu, M.J.; Nurmandi, A.; Salahudin; Qodir, Z.; Sihidi, I.T.; Lutfi, M. How Public Transportation Use Social Media Platform during Covid-19: Study on Jakarta Public Transportations' Twitter Accounts? Webology 2021, 18, 1-19. [CrossRef]

26. FAO State of the World's Forests 2007-Africa. State World For. 2007, 5, 273-279. 
27. Agovino, M.; Garofalo, A.; Cerciello, M. Do local institutions affect labour market participation? The Italian case. BE J. Econ. Anal. Policy 2019, 19, 2. [CrossRef]

28. Purnomo, E.P.; Ramdani, R.; Salsabila, L.; Choi, J.-W. Challenges of community-based forest management with local institutional differences between South Korea and Indonesia. Dev. Pract. 2020, 30, 1-12. [CrossRef]

29. Brockhaus, M.; Obidzinski, K.; Dermawan, A.; Laumonier, Y.; Luttrell, C. An overview of forest and land allocation policies in Indonesia: Is the current framework sufficient to meet the needs of REDD+? For. Policy Econ. 2012, 18, 30-37. [CrossRef]

30. Suhardi; Faridah, E.; Handojo, H.N. Rehabilitation of degraded forests in Indonesia. World Bank Tech. Pap. 2016, $270,27-56$.

31. Nurmandi, A.; Purnomo, E.P. Making the Strategic Plan Work in Local Government: A Case Study of Strategic Plan Implementation in Yogyakarta Special Province (YSP). Int. Rev. Public Adm. 2011, 16, 143-164. [CrossRef]

32. Anand, P.B. Right to information and local governance: An exploration. J. Hum. Dev. Capab. 2011, 12, 135-151. [CrossRef]

33. Osei-Tutu, P.; Pregernig, M.; Pokorny, B. Interactions between formal and informal institutions in community, private and state forest contexts in Ghana. For. Policy Econ. 2015, 54, 1. [CrossRef]

34. Mcallister, I. The Personalization of Politics. In The Oxford Handbook of Political Behavior; Oxford University Press: Oxford, UK, 2009; ISBN 9780191577178.

35. Andersson, K. Local Governance of Forests and the Role of External Organizations: Some Ties Matter More Than Others. World Dev. 2013, 43, 226-237. [CrossRef]

36. Tie, L.; Feng, M.; Huang, C.; Peñuelas, J.; Sardans, J.; Bai, W.; Han, D.; Wu, T.; Li, W. Soil Cover Improves Soil Quality in a Young Walnut Forest in the Sichuan Basin, China. Forests 2021, 12, 236. [CrossRef]

37. Purnomo, E.P.; Zahra, A.A.; Malawani, A.D.; Anand, P. The Kalimantan Forest Fires: An Actor Analysis Based on Supreme Court Documents in Indonesia. Sustainability 2021, 13, 2342. [CrossRef]

38. Hanna, S.; Folke, C.; Maler, K.G. Property rights and environmental resources. In Property Rights and the Environment: Social and Ecological Issues; The World Bank: Wahsingthon, DC, USA, 1995.

39. Dewi, A.; Nurmandi, A.; Rochmawati, E.; Purnomo, E.P.; Dimas Rizqi, M.; Azzahra, A.; Benedictos, S.; Suardi, W.; Tri Kusuma Dewi, D. Global policy responses to the COVID-19 pandemic: Proportionate adaptation and policy experimentation: A study of country policy response variation to the COVID-19 pandemic. Health Promot. Perspect. 2020, 10, 359-365. [CrossRef] [PubMed]

40. Gaveau, D.L.A.; Sloan, S.; Molidena, E.; Yaen, H.; Sheil, D.; Abram, N.K.; Ancrenaz, M.; Nasi, R.; Quinones, M.; Wielaard, N.; et al. Four decades of forest persistence, clearance and logging on Borneo. PLoS ONE 2014, 9, e101654. [CrossRef]

41. Purnomo, E.P.; Ramdani, R.; Agustiyara; Tomaro, Q.P.V.; Samidjo, G.S. Land ownership transformation before and after forest fires in Indonesian palm oil plantation areas. J. Land Use Sci. 2019, 11, 1-15.

42. Hair, J.F.; Sarstedt, M.; Hopkins, L.; Kuppelwieser, V.G. Partial least squares structural equation modeling (PLS-SEM): An emerging tool in business research. Eur. Bus. Rev. 2014, 26, 106-121. [CrossRef]

43. Agustiyara; Purnomo, E.P.; Ramdani, R. Using Artificial Intelligence Technique in Estimating Fire Hotspots of Forest Fires. IOP Conf. Ser. Earth Environ. Sci. 2021, 717, 12019. [CrossRef]

44. Tenenhaus, M. Component-based structural equation modelling. Total Qual. Manag. Bus. Excell. 2008, 19, 7. [CrossRef]

45. Benitez, J.; Henseler, J.; Castillo, A.; Schuberth, F. Information \& Management How to perform and report an impactful analysis using partial least squares: Guidelines for confirmatory and explanatory IS research. Inf. Manag. 2020, $57,103168$.

46. Kim, Y.S.; Bae, J.S.; Fisher, L.A.; Latifah, S.; Afifi, M.; Lee, S.M.; Kim, I.A. Indonesia's Forest Management Units: Effective intermediaries in REDD+ implementation? For. Policy Econ. 2016, 62, 69-77. [CrossRef]

47. Jupesta, J.; Boer, R.; Parayil, G.; Harayama, Y.; Yarime, M.; De Oliveira, J.A.P.; Subramanian, S.M. Managing the transition to sustainability in an emerging economy: Evaluating green growth policies in Indonesia. Environ. Innov. Soc. Transit. 2011, 1, 187-191. [CrossRef]

48. Koroso, N.H.; Zevenbergen, J.A.; Lengoiboni, M. Land institutions' credibility: Analyzing the role of complementary institutions. Land Use Policy 2019, 81, 553-564. [CrossRef]

49. Agovino, M.; Cerciello, M.; Ferraro, A.; Garofalo, A. Spatial analysis of wildfire incidence in the USA: The role of climatic spillovers. Environ. Dev. Sustain. 2021, 23, 6084-6105. [CrossRef]

50. Falk, R.; Miller, N.B. A Primer for Soft Modeling. Open J. Bus. Manag. 2014, 21, 32-38.

51. Zhang, J.; Liu, H.; Sayogo, D.S.; Picazo-Vela, S.; Luna-Reyes, L. Strengthening institutional-based trust for sustainable consumption: Lessons for smart disclosure. Gov. Inf. Q. 2016, 33, 552-561. [CrossRef]

52. Kahsay, G.A.; Bulte, E. Trust, regulation and participatory forest management: Micro-level evidence on forest governance from Ethiopia. World Dev. 2019, 120, 118-132. [CrossRef]

53. Ananda, J.; Proctor, W. Collaborative approaches to water management and planning: An institutional perspective. Ecol. Econ. 2013, 86, 97-106. [CrossRef]

54. Yew, W.L.; Zhu, Z. Innovative autocrats? Environmental innovation in public participation in China and Malaysia. J. Environ. Manage. 2019, 234, 28-35. [CrossRef]

55. Gustafsson, M.T.; Scurrah, M. Unpacking the extractivist state: The role of weak state agencies in promoting institutional change in Peru. Extr. Ind. Soc. 2019, 6, 206-214. [CrossRef]

56. Dickinson, J.L.; Shirk, J.; Bonter, D.; Bonney, R.; Crain, R.L.; Martin, J.; Phillips, T.; Purcell, K. The current state of citizen science as a tool for ecological research and public engagement. Front. Ecol. Environ. 2012, 10, 291-297. [CrossRef] 
57. Song, A.M.; Temby, O.; Kim, D.; Saavedra, A.; Hickey, G.M. Measuring, mapping and quantifying the effects of trust and informal communication on transboundary collaboration in the Great Lakes fisheries policy network. Glob. Environ. Chang. 2019, 54, 6-18. [CrossRef]

58. Ansell, C.; Gash, A. Collaborative Governance in Theory and Practice. JPART 2007, 18, 543-571. [CrossRef]

59. Lockwood, M. Good governance for terrestrial protected areas: A framework, principles and performance outcomes. J. Environ. Manage. 2010, 91, 754-766. [CrossRef] [PubMed]

60. Ostrom, E. Crossing the great divide. Co-production, synergy \& development, polycentric governace and development. World Dev. 2009, 24, 1073-1087.

61. FAO. The State of Food Insecurity in the World 2012; FAO: Rome, Italy, 2012; ISBN 9789251073162.

62. Gbedomon, R.C.; Floquet, A.; Mongbo, R.; Salako, V.K.; Fandohan, A.B.; Assogbadjo, A.E.; Glèlè Kakayi, R. Socio-economic and ecological outcomes of community based forest management: A case study from Tobé-Kpobidon forest in Benin, Western Africa. For. Policy Econ. 2016, 64, 46-55. [CrossRef]

63. Larson, A. Network Dyads in Entrepreneurial Settings: A Study of the Governance of Exchange Relationships. Adm. Sci. Q. 2006, 37, 76-104. [CrossRef]

64. Sunderlin, W.D. Poverty alleviation through community forestry in Cambodia, Laos, and Vietnam: An assessment of the potential. For. Policy Econ. 2006, 8, 386-396. [CrossRef] 